\title{
Ion regulation in two species of estuarine crabs
}

\author{
Paul A. Dehnel \\ Department of Zoology, University of British Columbia, Vancouver, Canada
}

Ionenregulation bei zwei Arten estuariner Kurzschwanzkrebse. Anmerkung der Schrifleitung: Professor DeHnels Beitrag zum I. Internationalen Symposion über Probleme der quanittativen Biologie des Stoffwechsels, Helgoland, 24. bis 26. September 1963, wird hier nur als Kurzfassung wiedergegeben. Teile seiner Ausführungen sind bereits an anderer Stelle publiziert worden.

In low salinities sodium, potassium and calcium ion concentrations in the blood of both species, Hemigrapsus nudus and $H$.oregonensis, are hypertonic to the media. In high salinities, ion regulation is less effective and concentrations approach isotonicity. This regulation is effected by extra-renal processes, since U/B ratios approximate unity. Blood concentration of magnesium is regulated in both species at a hypotonic level, one-third that of the medium concentration in all salinities. It is suggested that the principal site of ion uptake from the medium in Hemigrapsus is the lamellar epithelium of the gill. Winter animals of both species appear to be more effective regulators of the calcium ion in low salinities. All other ion concentrations are similar, summer and winter. No consistent temperature effect could be demonstrated for ion concentration in blood or urine. The principal function of the antennary glands is to maintain a blood magnesium concentration hypotonic to all salinities. It is suggested that this regulation of magnesium is necessary to facilitate neuromuscular transmission and is a characteristic feature of ion regulation in active decapod crustacea. Ion regulatory ability of the two species differed only with respect to winter blood levels of sodium. H. oregonensis more effectively regulates this ion at hypotonic blood levels in high salinities.

Chloride regulation in the two species demonstrates that the blood is hyperosmotic in low salinities and hyposmotic in higher salinities. Urine is hyperosmotic over the entire salinity range and is approximately 35 to $40 \%$ higher than the blood. Blood concentrations of chloride approximate a gradient of 15 to $30 \%$ above the experimental media. U/B ratios suggest that the antennary gland is not solely responsible for the regulation of this ion.

Chloride regulation in the muscle of $H$. nudus demonstrates that in a high blood chloride environment, muscle chloride remains low, about one-third that of blood.

Consideration of muscle cations of $H$. nudus shows that blood sodium is about

1 Brief outline of a paper presented at the I. International Symposium on Problems of Quantitative Biology of Metabolism, Helgoland, September 24-26, 1963. 
5 times greater than muscle, whereas muscle potassium is about 8 times greater than that concentration in the blood. Muscle sodium and potassium are similar except at high salinities, where sodium rises rapidly. Blood calcium is concentrated about 3 times that of muscle, and if muscle magnesium is in higher concentration at low salinities, then the blood concentration of magnesium becomes hypertonic, and urine magnesium rises sharply. This suggests that magnesium moves from muscle to blood to urine and relates to the high urine output of magnesium in high salinities.

\section{Discussion following the paper by DEHNEL}

KINNE: You have mentioned as an extra-renal route of excretion, the route via the gill tissue. How about the gut? We have information from other crustaceans indicating that the gut may be considered a site of extra-renal excretion or uptake of water and salt respectively.

DEHNEL: We have no data as far as the gut is concerned with respect to extra-renal excretion. However, we have information which supports the second feature, namely, ion uptake (a) through the food, (b) through the gut; this may account for the way in which an animal may obtain ions initially against a gradient.

KINNE: If I have understood you correctly, you have pointed out in your presentation that salinity increase leads to a decrease in muscle water while blood water remains more or less constant, perhaps with a slight tendency to decrease. What would be the minimum amount of muscle water maintained?

DenNex: In high salinities, muscle water is approximately $70 \%$. In low salinities, it is approximately $80 \%$.

KINNE: How do you interpret these results? Do you feel that muscle water could play a compensatory role, say as an extra-vascular water pool? This would be an analogy to the respective salt pools described for isopods.

DeHnel: Yes it seems to look as if there may be a mechanism whereby muscles may serve as water storage, and changes in muscle water may represent a condition, with respect to water, analogous to the described salt pool. In the higher concentrations there is a movement of water from the muscle into the blood.

URICH: Ist bei der Bestimmung der Ionenkonzentrationen im Muskel der Gehalt der Muskelproben an extrazellulärer Flüssigkeit berücksichtigt worden?

DEHNEL: This is exactly the stage at which $\mathrm{I}$ am at at the present time - the determination of this extra-cellular water. The crab, as you know, with the open circulatory system has a very large extra-cellular area, and undoubtedly much will be explained on this basis. 